Proceedings

\title{
Antiproliferative and Apoptotic Activity of Polyphenol-Rich Crude Methanol Extract of Gracillaria edulis against Human Rhabdomyosarcoma (Rd) and Breast Adenocarcinoma (Mcf-7) Cell Lines ${ }^{\dagger}$
}

Thilina Lakmini Gunathilaka ${ }^{1, *}$, Kalpa Samarakoon ${ }^{2}$, Pathmasiri Ranasinghe ${ }^{3}$ and Dinithi Champika Peiris ${ }^{4, *}$

Citation: Gunathilaka, T.L.; Samarakoon, K.; Ranasinghe, P; Peiris, D.C. Antiproliferative and Apoptotic Activity of PolyphenolRich Crude Methanol Extract of Gracillaria edulis against Human Rhabdomyosarcoma (Rd) and Breast Adenocarcinoma (Mcf-7) Cell Lines. Proceedings 2021, 79, 6. https://doi. org/10.3390/IECBM2020-08655

Published: 1 December 2020

Publisher's Note: MDPI stays neutral with regard to jurisdictional claims in published maps and institutional affiliations.

Copyright: $(2020$ by the authors. Licensee MDPI, Basel, Switzerland. This article is an open access article distributed under the terms and conditions of the Creative Commons Attribution (CC BY) license (http://creativecommons.org/licenses/by/4.0/).
1 Department of Zoology (Center for Instrumentation Facility), Faculty of Applied Sciences, University of Sri Jayewardenepura, Nugegoda 10250, Sri Lanka

2 KDU Institute for Combinatorial Advanced Research and Education (KDU-CARE), General Sir John Kotelawala Defence University, Kandawala Road, Rathmalana 10390, Sri Lanka; kalpa.samarakoon@gmail.com

3 Industrial Technology Institute, Halbarawa Gardens, Malabe 10115, Sri Lanka; pathmasiri@iti.lk

4 Department of Zoology/Genetics \& Molecular Biology Unit (Center for Biotechnology), Faculty of Applied Sciences, University of Sri Jayewardenepura, Nugegoda 10250, Sri Lanka

* Correspondence: gunathilakathilina2@gmail.com (T.L.G.); dinithi@sci.sjp.ac.lk (D.C.P.); Tel.: +94-714-018-537 (D.C.P.)

+ Presented at the 1st International Electronic Conference on Biomolecules: Natural and Bio-Inspired Therapeutics for Human Diseases, 1-13 December 2020; Available online: https://iecbm2020.sciforum.net/.

\begin{abstract}
Seaweeds are an important source of bioactive metabolites in the development of drugs and nutraceuticals. This study aimed to analyze the antiproliferative and apoptotic activities of the methanol extract (ME) of G. edulis using human Rhabdomyosarcoma (RD) and breast adenocarcinoma (MCF-7) cells. De-polysaccharide ME of G. edulis was extracted to determine antiproliferative and apoptotic activity. The cytotoxic activity was evaluated by 3-(4,5-dimethylthiazol-2-cyl)-2,5-diphenyltetrazolium bromide (MTT) and neutral red uptake assay, while apoptotic activity was characterized by cellular morphology, DNA fragmentation, and caspase 3/7 assay. The cytotoxicity assay results showed that the decrease in the percentage of cell viability did so in a dose-dependent manner, as signified by cell death. The apoptosis was induced by activating the caspase 3/7 pathway, and the RD cell line showed prominent activation of caspase 3 compared to the MCF-7 cells with low activation. Further, the typical DNA ladder pattern was observed in RD cells, whereas MCF-7 cells did not show a characteristic ladder pattern. Thus, it can be concluded that the ME of G. edulis possesses anticancer activity via activating the caspase pathway.
\end{abstract}

Keywords: G. edulis; anticancer; rhabdomyosarcoma; MCF-7; MTT; neutral red; caspase pathway

\section{Introduction}

Recently, the burden of different types of cancer increased significantly around the globe. The World Health Organization projects that, by 2035, the world could see 24 million new cancer cases and 14.5 million cancer-related deaths a year [1]. According to the Cancer Registry of Sri Lanka, about 23,530 cancer cases were reported in 2018, accompanied by 14,013 deaths [2]. Breast cancer, skin cancer, and ovarian cancer are the leading cancers affecting women globally [1]. Also, soft tissue sarcoma is the third most common solid tumor in children [3]. Available cancer treatments cause several side effects with an increased risk of developing secondary cancers due to their long-term potential toxic effects. Hence, it is vital to keep searching for an effective drug with minimum side effects that may benefit patients suffering from different cancer types [4]. Among the natural 
resources, seaweeds play a significant role in drug development due to bioactive secondary metabolites that exhibit potent biological activity such as antioxidant, anticancer, antidiabetic, etc. Gracillaria edulis (Gmelin) Silva is a red alga that belongs to the family Gracilariaceae. Polyphenols purified from red seaweeds are considered a rich source of antioxidants. In the search for new plant-derived drugs, natural antioxidant-rich marine seaweeds can be utilized to develop potential anticancer therapies. Therefore, the present study aimed to analyze the antiproliferative and apoptotic activity of the methanol extract of G. edulis on human Rhabdomyosarcoma (RD) and human breast adenocarcinoma (MCF-7) cell lines.

\section{Materials and Methods}

\subsection{Collection of Red Algae Gracillaria edulis}

Permission to collect the algae sample was obtained from the Department of Wildlife Conservation (permit number-WL/3/280/17). The red algae Gracillaria edulis was manually collected from the Kalpitiya lagoon area, Puttalam $\left(8^{\circ} 14^{\prime} 0^{\prime \prime} \mathrm{N}, 79^{\circ} 46^{\prime} 0^{\prime \prime}\right.$ E), Sri Lanka, and the specimen of algae sample was deposited at the Department of Zoology, University of Sri Jayewardenepura. The collected samples were cleaned and washed with fresh water to remove salt, sand, attached epiphytes, and organic matter. The samples were airdried and ground into a fine powder and stored at $-20^{\circ} \mathrm{C}$ until further use.

\subsection{Preparation of The Methanol Extract}

Homogenized G. edulis powder (10 g) was extracted three times using $70 \%$ methanol, subjected to sonication at $25^{\circ} \mathrm{C}$ for three 90 min periods. The polyphenols were separated by precipitating crude polysaccharides using $70 \%$ ethanol $(1: 20 \mathrm{v} / \mathrm{v})$. The supernatant was separated as polyphenol-rich methanol extract [5].

\subsection{Maintenance of Cell Lines}

Human rhabdomyosarcoma (RD) and breast adenocarcinoma (MCF-7) cells were a kind gift of Dr. Chamindri Vitharana, Department of Biochemistry, Faculty of Medical Sciences, University of Colombo. The cells were cultured in high glucose DMEM medium supplemented with 10\% v/v FBS and 1\% penicillin-streptomycin antibiotic solution. The cells were maintained in a $5 \% \mathrm{CO}_{2}$ incubator at $37^{\circ} \mathrm{C}$.

\subsection{In Vitro Antiproliferative and Apoptotic Activity}

In vitro cytotoxic activity was determined by 3-(4,5-dimethylthiazol-2-cyl)-2,5-diphenyltetrazolium bromide (MTT) and neutral red assays [6].

\subsubsection{MTT Assay}

Cells were seeded in a 96-well plate at a density of $1 \times 105$ cells/well and incubated in FBS and antibiotic supplemented DMEM medium at $37^{\circ} \mathrm{C}$ for $24 \mathrm{~h}$. After incubation for $24 \mathrm{~h}$, cells were treated with the different concentrations $(10,20,30,40,50,60 \mu \mathrm{g} / \mathrm{mL})$ of the extract. Following $24 \mathrm{~h}$ of incubation, stock MTT solution (10/ 1 per 100/ 1 medium) was added to all wells of an assay, and plates were incubated at $37^{\circ} \mathrm{C}$ for $4 \mathrm{~h}$. After incubation, $10.04 \mathrm{~N} \mathrm{HCI}$ in isopropanol was added to all wells and mixed thoroughly to dissolve the dark blue crystals. The plates were read using SPECTRAmax-Gemini EM, Molecular Devices Inc, San Jose, CA, USA, with a wavelength of $570 \mathrm{~nm}$.

\subsubsection{Neutral Red Assay}

Cells were seeded in a 96-well plate at a density of $1 \times 105$ cells/well and incubated in FBS and antibiotic supplemented DMEM medium at $37^{\circ} \mathrm{C}$ for $24 \mathrm{~h}$. After incubation for $24 \mathrm{~h}$, cells were treated with the different concentrations $(10,20,30,40,50,60 \mu \mathrm{g} / \mathrm{mL})$ of the extract. Following $24 \mathrm{~h}$ of incubation, $0.04 \mathrm{mg} / \mathrm{mL}$ neutral red dye was added to all wells, and cells were incubated for 2-4 h. After the incubation, cells were washed with a 
neutral red washing solution and rinsed with neutral red solubilization solution. The plates were read using SPECTRAmax-Gemini EM, Molecular Devices Inc., San Jose,CA, USA, with a wavelength of $540 \mathrm{~nm}$.

Apoptotic activity was characterized by cellular morphology, DNA fragmentation, and caspase 3/7 assay [7]. The caspase-3/7 activity of RD and MCF-7 cells was determined according to the manufacturer's instructions of the caspase-3/7 fluorescence Assay Kit.

\section{Results}

\subsection{In Vitro Cytotoxic Activity}

The cytotoxic activity results against the human RD and MCF-7 cells as determined by MTT, and neutral red assays are shown in Table 1. The results exhibited a dose-dependent decrease in cell viability as signified by cell death. The extract of G. edulis exhibited potent cytotoxicity against RD (IC50: $49.86 \pm 0.02 \mu \mathrm{g} / \mathrm{mL}$ ) and MCF-7 (IC50: $34.43 \pm 0.86$ $\mu \mathrm{g} / \mathrm{mL}$ ) carcinoma cells when compared to the standard cycloheximide (IC50RD: $36.17 \pm$ $1.78 \mu \mathrm{g} / \mathrm{mL} ; \mathrm{IC}_{50 \mathrm{MCF}-7:} 28.76 \pm 0.55 \mu \mathrm{g} / \mathrm{mL}$ ) as confirmed by the MTT assay. The neutral red assay further confirmed the potential cytotoxic activity of the extract (IC50RD: $33.47 \pm 2.25$ $\mu \mathrm{g} / \mathrm{mL}$; IC50MCF-7: $35.13 \pm 0.95 \mu \mathrm{g} / \mathrm{mL}$ ) against RD and MCF-7, compared to the standard cycloheximide (IC50RD: $32.78 \pm 0.91 \mu \mathrm{g} / \mathrm{mL}$; IC50MCF-7: $27.84 \pm 0.33 \mu \mathrm{g} / \mathrm{mL}$ ) which can act as a protein synthesis inhibitor in eukaryotes.

Table 1. Apoptotic activity of the methanol extract of G. edulis and standard cycloheximide. Against RD and MCF-7 cells after $24 \mathrm{~h}$ of treatment.

\begin{tabular}{lcccc}
\hline \multirow{2}{*}{ Extracts } & \multicolumn{4}{c}{ IC $_{50}$ Value $(\mu \mathrm{g} / \mathrm{mL})$} \\
\cline { 2 - 5 } & \multicolumn{2}{c}{ MTT Assay } & Neutral Red Assay \\
\cline { 2 - 5 } & RD Cells & MCF-7 Cells & RD Cells & MCF-7 Cells \\
\hline G. edulis methanol extract & $49.86 \pm 0.02$ & $34.43 \pm 0.86$ & $33.47 \pm 2.25$ & $35.13 \pm 0.95$ \\
\hline Standard Cycloheximide & $36.17 \pm 1.78$ & $28.76 \pm 0.55$ & $32.78 \pm 0.91$ & $27.84 \pm 0.33$ \\
\hline RD (human Rhabdomyosarcoma). & & &
\end{tabular}

RD (human Rhabdomyosarcoma).

\subsection{Apoptotic Activity}

The apoptotic activity of RD and MCF-7 cells after $24 \mathrm{~h}$ of the treatment with the methanol extract was characterized by cellular morphology, DNA fragmentation, and caspase 3/7 assay. As shown in Figure 1, a prominent activation of caspase 3/7 was observed in the RD cells compared to the MCF-7 cells. Additionally, the highest caspase 3/7 activity was observed after $4 \mathrm{~h}$ in RD cells, whereas in MCF-7 high caspase activity was observed after $3 \mathrm{~h}$ of the treatment.

Similarly, the DNA ladder pattern was observed in RD cells treated with methanol extract and the standard cycloheximide, whereas MCF-7 cells did not show any typical DNA ladder pattern (Figure 2).

Further, apoptotic morphological features of RD and MCF-7 cells were observed using the fluorescence staining (Hoechst stain) method in addition to the phase-contrast inverted microscope. As shown in Figure 3, treated cells with G. edulis methanol extract and standard staurosporine displayed typical morphological features compared to the untreated cells (control). 


\section{Caspase $3 / 7$ activity of RD and MCF-7 cells}

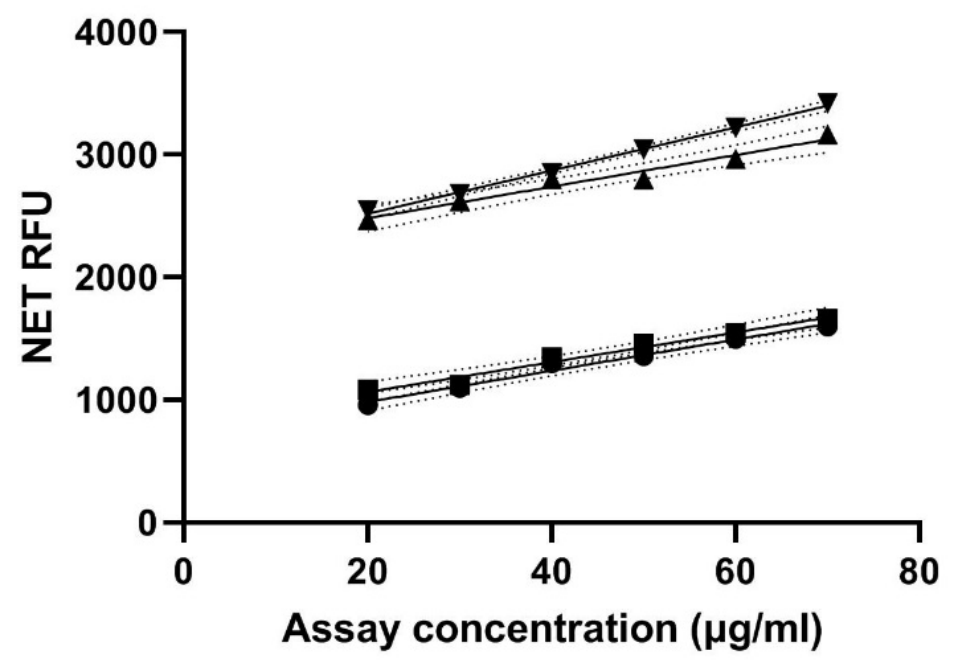

MCF-7-Methanol extract

- after 3 hrs of the treatement

MCF-7 Standard after $3 \mathrm{hrs}$ of the treatement

$\mathrm{RD}$-Methanol extract

$\star$ after 4 hrs of the treatement

$\rightarrow$ RD Standard after 4 hrs of the treatement

Figure 1. Caspase 3/7 activity of MCF-7 and RD cells obtained after $24 \mathrm{~h}$ of treatment with various concentrations of the methanol extract of G. edulis and standard Staurosporine. Data are shown as mean \pm SD of triplicates.

\section{$\begin{array}{llllll}1 & 2 & 3 & 4 & 5 & 6\end{array}$}

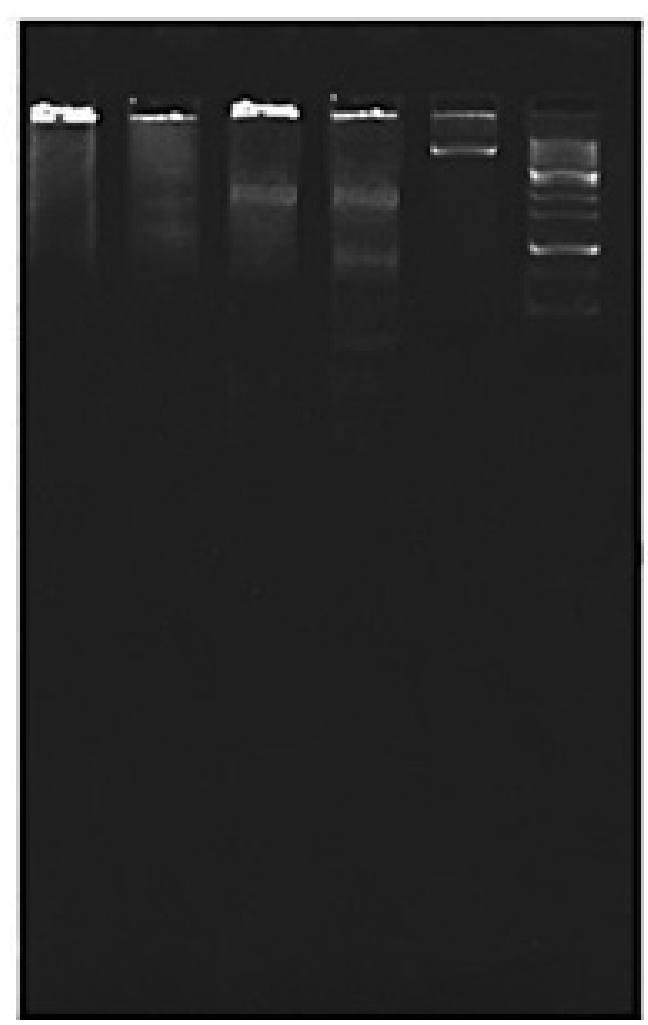

Figure 2. DNA fragmentation gel picture of MCF-7 $(30 \mu \mathrm{g} / \mathrm{mL})$ and $\mathrm{RD}(50 \mu \mathrm{g} / \mathrm{mL})$ cells treated with G. edulis methanol extract and standard cycloheximide $(30 \mu \mathrm{g} / \mathrm{mL})$. 1: methanol extract treated MCF7 cells; 2 : standard cycloheximide treated MCF-7 cells; 3 : methanol extract treated RD cells; 4: standard cycloheximide treated RD cells; 5: control (untreated); 6: DNA ladder. 
RD-CONTROL

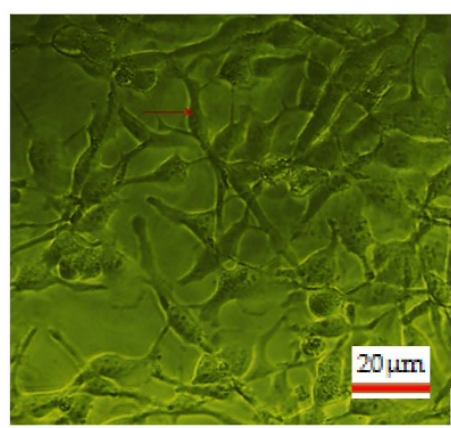

MCF-7-CONTROL

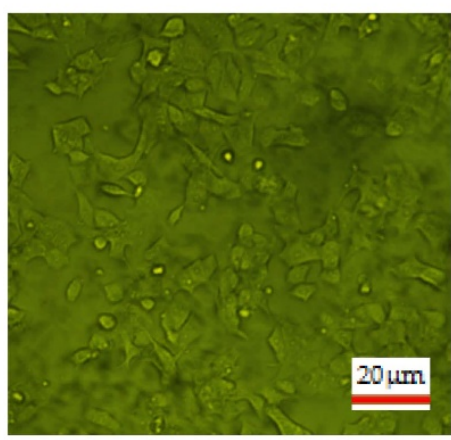

RD-STANDARD: $30 \mu \mathrm{g} / \mathrm{mL}$

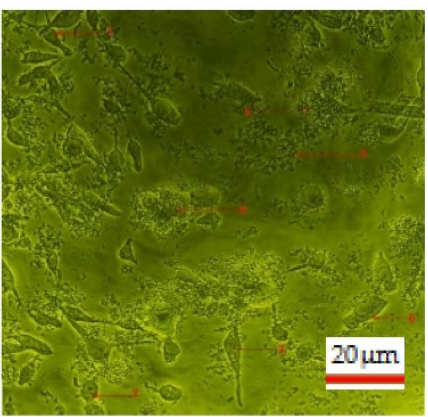

MCF-7-STANDARD: $30 \mu \mathrm{g} / \mathrm{mL}$

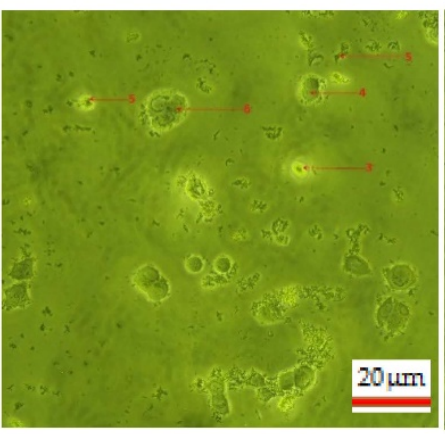

RD-ME: $50 \mu \mathrm{g} / \mathrm{mL}$

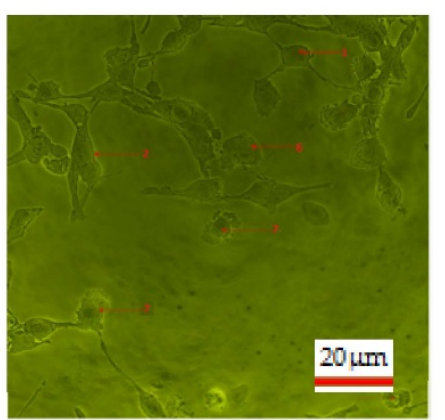

MCF-7-ME: $30 \mu \mathrm{g} / \mathrm{mL}$

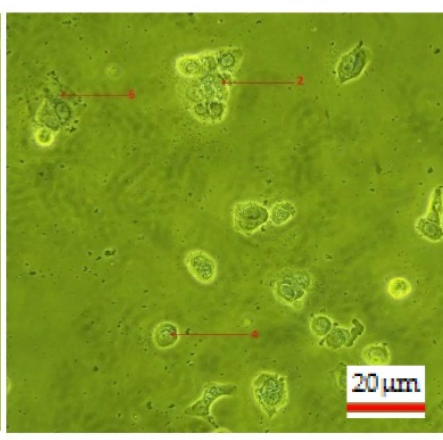

Figure 3. Phase contrast inverted microscopic images of the enriched fraction of G. edulis methanol extract and standard cycloheximide in human RD and MCF-7 cell lines. Apoptotic morphological features: 1. cells with normal nuclei; 2 . cellular aggregation and formation of cell clumps; 3 . chromatin condensation; 5 . cell shrinkage and cellular death; 6. cell membrane blebbing.

\section{Discussion}

The present study showed the potent cytotoxic and apoptotic effects of methanol extract of G. edulis against human RD and MCF-7 cell lines. The G. edulis methanol extract can reduce the cell count (visible) and caused the apoptotic response.

According to the cytotoxic assay, higher cytotoxicity was observed in the RD cells treated with the methanol extract of G. edulis compared to the MCF-7 cells, as determined by MTT and neutral red assays. When comparing the cytotoxicity results, both MTT and neutral red assays showed more or less similar results as both assays measure the cell viability using different approaches. The MTT assay is based on reducing yellow tetrazolium MTT reagent to purple formazan crystals by cellular oxidoreductase enzymes present in mitochondria of viable cells. In contrast, the neutral red assay is based on the accumulation of neutral red dye, which is a eurhodin dye in the lysosomes of viable cells [8].

Lakshmi et al. (2016) found that the antiproliferative activity of the methanol extract of G. edulis was $89.35 \%$ cell viability for $100 \mu \mathrm{g}$ of methanol extract against MCF-7 cell line [9]. In the present study, $69.70 \%$ of cell viability was observed for $20 \mu \mathrm{g} / \mathrm{mL}$ of methanol extract. The observed high anti-inhibitory activity of the present study might be due to the variation in extraction techniques. The current research extracted only the polyphenolic portion using the sonication method. In contrast, the previous analysis was against the whole crude algae using the Soxhlet method for extraction.

Apoptosis is the programmed cell death that is regulated by different families of proteins. Among them, caspase is an important protein family involved in the cell death pathway (apoptosis). Caspase proteins are arranged in a cascade and coordinate the stereotypical events during apoptosis by transmitting the death signal. Among the different types of caspases, caspase 3 is essential in the process of apoptosis as it is activated by both intrinsic (mitochondrial) and extrinsic (death ligand) pathways. The activation of caspase 
3 leads to the cleavage of different structural proteins such as poly(ADP-ribose) polymerase, caspase-activated DNase (ICAD), and DNA fragmentation factor, resulting in morphological alterations of cells such as cell membrane blebbing and cellular condensation. Further, DNA fragmentation apoptosis resulted in the cleavage of caspase-activated DNase (ICAD) [10].

In addition to caspase 3, caspase 7 is also an executioner protein of apoptosis, activated by cell death stimuli to induce apoptosis [11]. In the present study, a prominent elevation of caspase $3 / 7$ was observed in the RD cells after the $4 \mathrm{~h}$ of treatment compared to the MCF-7 cells. The results of the present study showed that the extract induces deficient activation of caspase 3/7 after $24 \mathrm{~h}$ of treatment. Further, Wang et al. (2016) documented that caspase 3 is deficient in MCF-7 due to the partial deletion of the CASP-3 gene important for cell death, thus leaving the MCF-7 cells without typical apoptotic properties [12]. The DNA ladder pattern of the extract-treated MCF-7 cells confirmed the absence of cpasae-3. However, one band observed in the MCF-7 cells treated with the standard due to caspase 7 activation caused cell membrane blebbing and DNA fragmentation [13].

During apoptosis, cells display typical morphological features such as cell membrane blebbing, membrane-bounded vesicle formation, nuclear fragmentation, micronuclei formation, cellular shrinkage, cellular aggregation, and formation of cell clumps, and chromatin condensation. Most of these features were observed in both RD and MCF-7 cells treated with the methanol extract of G. edulis and standard cycloheximide compared to the untreated cells.

\section{Conclusions}

It can be concluded that the crude methanol extract of G. edulis exhibits significant antiproliferative and apoptotic activity against RD and MCF-7 cell lines. The RD cell line showed prominent activation of caspase 3 compared to the MCF-7 cells, which have low activation.

Author Contributions: Conceptualization, D.C.P., P.R. and K.S.; methodology, D.C.P., P.R. and K.S.; software, T.L.G.; formal analysis, T.L.G., and P.R.; investigation, T.L.G., and P.R.; data curation, T.L.G.; writing-original draft preparation, T.L.G.; writing-review and editing, D.C.P., and K.S.; supervision, D.C.P., P.R. and K.S.; project administration, D.C.P.; funding acquisition, D.C.P. All authors have read and agreed to the published version of the manuscript.

Funding: This research was funded by the University of Sri Jayewardenepura, Sri Lanka (ASP/01/RE/SCI/2017/50).

Institutional Review Board Statement: Not applicable.

Informed Consent Statement: Not applicable.

Data Availability Statement: Not applicable.

Conflicts of Interest: The authors declare no conflict of interest.

\section{References}

1. World Health Organization. Cancer. 2017. Available online: http://www.who.int/mediacentre/factsheets/fs297/en/ (accessed on 12 November 2020).

2. BC Cancer Agency. BC Cancer Registry Annual Report. 2018. Available online: http://www.bccancer.bc.ca/about-site/Documents/BCCancerResearch-AnnualReport2018.pdf (accessed on 15 November 2020).

3. Hettmer, S.; Li, Z.; Billin, A.N.; Barr, F.G.; Cornelison, D.D.W.; Ehrlich, A.R.; Guttridge, D.C.; Hayes-Jordan, A.; Helman, L.J.; Houghton, P.J.; et al. Rhabdomyosarcoma: Current Challenges and Their Implications for Developing Therapies. Cold Spring Harb. Perspect. Med. 2014, 4, a025650.

4. Fourquet, A.; Kirova, Y.; Bollet, M.; Tournat, H.; Dendale, R.; Campana, F. Meta-analyses of the effects of radiotherapy in breast cancer: The ultimate evidence. Cancer 2008, 12, 554-558.

5. Lakmal, H.; Samarakoon, K.; Lee, W.; Lee, J.; Abeytunga, D.; Lee, H.; Jeon, Y. Anticancer and antioxidant effects of selected Sri Lankan marine algae. J. Natl. Sci. Found. Sri Lanka 2014, 42, 315.

6. Mosmann, T. Rapid Colorimetric Assay for Cellular Growth and Survival: Application to Proliferation and Cytotoxicity Assays. J. Immunol. Methods 1983, 65, 55-63. 
7. Arumugam, A.; Ibrahim, M.D.; Kntayya, S.B.; Ain, N.M.; Iori, R.; Galletti, S.; Ioannides, C.; Razis, A.F.A. Induction of Apoptosis by Gluconasturtiin-Isothiocyanate (GNST-ITC) in Human Hepatocarcinoma HepG2 Cells and Human Breast Adenocarcinoma MCF-7 Cells. Molecules 2008, 25, 1240, doi:10.3390/molecules25051240.

8. Green, L.M.; Reade, J.L.; Ware, C.F. Rapid colormetric assay for cell viability: Application to the quantitation of cytotoxic and growth inhibitory lymphokines. J. Immunol. Methods 1984, 70, 257-268, doi:10.1016/0022-1759(84)90190-X.

9. Sheeja, L.; Lakshmi, D.; Bharadwaj, S.; Parveen, K.S. Anticancer activity of phytol purified from Gracilaria edulis against human breast cancer cell line (MCF-7). Int. J. Curr. Sci. 2016, 19, 36-46.

10. Ponder, K.G.; Boise, L.H. The prodomain of caspase-3 regulates its own removal and caspase activation. Cell Death Discov. 2019, 5, 1-10, doi:10.1038/s41420-019-0142-1.

11. Lamkanfi, M.; Kanneganti, T.-D. Caspase-7: A protease involved in apoptosis and inflammation. Int. J. Biochem. Cell Biol. 2010, 42, 21-24, doi:10.1016/j.biocel.2009.09.013.

12. Wang, S.; He, M.; Li, L.; Liang, Z.; Zou, Z.; Tao, A. Breast Cancer Cell-in-Cell Death Is Not Restricted by Caspase-3 Deficiency in MCF-7 Cells. J. Breast Cancer 2016, 19, 231-241.

13. Mc Gee, M.M.; Hyland, E.; Campiani, G.; Ramunno, A.; Nacci, V.; Zisterer, D.M. Caspase-3 is not essential for DNA fragmentation in MCF-7 cells during apoptosis induced by the pyrrolo-1, 5-benzoxazepine, PBOX-6. FEBS Lett. 2002, 515, 66-70. 